\title{
Testicular Atrophy and Hypothalamic Pathology in COVID-19: Possibility of the Incidence of Male Infertility and HPG Axis Abnormalities
}

\author{
Kaviya Selvaraj ${ }^{1,2} \cdot$ Sowbarnika Ravichandran ${ }^{1,2}$. Sushmita Krishnan ${ }^{1} \cdot$ Risna Kanjirassery Radhakrishnan ${ }^{2}$. \\ Nivethitha Manickam ${ }^{2} \cdot$ Mahesh Kandasamy ${ }^{1,2,3}$ (I)
}

Received: 12 July 2020 / Accepted: 16 December 2020 / Published online: 7 January 2021

(C) Society for Reproductive Investigation 2021

\begin{abstract}
Coronavirus disease 2019 (COVID-19), which resulted from the pandemic outbreak of the severe acute respiratory syndrome coronavirus 2 (SARS-CoV-2), causes a massive inflammatory cytokine storm leading to multi-organ damage including that of the brain and testes. While the lungs, heart, and brain are identified as the main targets of SARS-CoV-2-mediated pathogenesis, reports on its testicular infections have been a subject of debate. The brain and testes are physiologically synchronized by the action of gonadotropins and sex steroid hormones. Though the evidence for the presence of the viral particles in the testicular biopsies and semen samples from COVID-19 patients are highly limited, the occurrence of testicular pathology due to abrupt inflammatory responses and hyperthermia has incresingly been evident. The reduced level of testosterone production in COVID19 is associated with altered secretion of gonadotropins. Moreover, hypothalamic pathology which results from SARS-CoV-2 infection of the brain is also evident in COVID-19 cases. This article revisits and supports the key reports on testicular abnormalities and pathological signatures in the hypothalamus of COVID-19 patients and emphasizes that testicular pathology resulting from inflammation and oxidative stress might lead to infertility in a significant portion of COVID-19 survivors. Further investigations are required to monitor the reproductive health parameters and HPG axis abnormalities related to secondary pathological complications in COVID-19 patients and survivors.
\end{abstract}

Keywords COVID-19 $\cdot$ SARS-CoV-2 $\cdot$ Testis $\cdot$ Hypothalamus $\cdot$ Inflammation $\cdot$ HPG axis

\section{Introduction}

In the current uncertain life-changing scenario, the entire world has been negatively impacted by the pandemic outbreak of severe acute respiratory syndrome coronavirus 2 (SARSCoV-2) $[1,2]$. Presently, persistent fever, chillness, cough, pneumonia, and loss of smell and taste have been considered as the emerging clinical symptoms of the SARS-CoV-2

Mahesh Kandasamy

pkmahesh5@gmail.com; mahesh.kandasamy@bdu.ac.in

1 School of Life Sciences, Bharathidasan University, Tiruchirappalli, Tamil Nadu 620024, India

2 Laboratory of Stem Cells and Neuroregeneration, Department of Animal Science, School of Life Sciences, Bharathidasan University, Tiruchirappalli, Tamil Nadu 620024, India

3 Faculty Recharge Programme, University Grants Commission (UGC-FRP), New Delhi 110002, India infection-mediated coronavirus disease 2019 (COVID-19) [3-5]. While a significant percentage of people with SARSCoV-2 infection are asymptomatic, clinical signs and pathogenesis of COVID-19 appear to vary among infected individuals depending upon the lifestyle, age, respiratory, metabolic, renal, and cardiovascular conditions [6-8]. SARS-CoV-2 causes several life-threatening clinical complications including acute respiratory distress syndrome (ARDS), cardiovascular failure, nervous system damage, gastrointestinal disorders, and renal dysfunctions in a considerable number of COVID19 patients worldwide [9-13]. However, SARS-CoV-2induced clinical outcome and pathogenic events during and post-recovery stages of COVID-19 are yet to be fully determined [8]. In general, the surface spike (S) viral proteins of SARS-CoV-2 have an affinity towards angiotensinconverting enzyme 2 (ACE2) and transmembrane serine protease 2 (TMPRSS2), through which it invades the host [14, 15]. Notably, ACE2 and TMPRSS 2 are expressed by various 
tissues and organs which have the potential risk of SARSCoV-2 infection leading to various pathological consequences [15-17]. While the lungs have been initially identified as the primary pathogenic targets of SARS-CoV-2, an increasing number of scientific evidence indicates comorbid clinical symptoms and multi-organ defects including the pathology of the testes and brain in COVID-19 patients [8, 18-21]. Notably, COVID-19 has been characterized by many neuropathological signatures due to the neuroinvasive attribute of SARS-CoV-2 [8, 12, 19, 22-25]. It has been reported that SARS-CoV-2 can cross the blood-brain barrier (BBB) and infect the ACE2 expressing neurons and glial cells, thereby leading to neuroinflammation and neuropathogenesis in the brain regions including the hypothalamus that controls various physiological functions like maintenance of the body temperature and hormonal balance $[8,12,17,25,26]$. Dysregulation of endocrine functions is an important clinical issue as it is related to different disorders including hypothyroidism, hypogonadism, anxiety, stress, and depression that are clearly evident in COVID-19 cases [27-30]. While the possible impact of COVID-19 on the abnormal hypothalamic-pituitaryadrenal (HPA) axis has been speculated [31], SARS-CoV-2mediated dysregulation of the hypothalamic-pituitary-gonadal (HPG) axis remains obscure. The brain and testes are endocrinologically linked by gonadotropins and testosterone through the regulation of the HPG feedback loop [30, 32]. While testes-derived circulating levels of sex steroid hormones are important for the regulation of the HPG axis and reproductive functions, COVID-19-associated testicular dysfunction, declined levels of testosterone and infertility require an intense scientific focus.

Initially, the testes were thought to be the target of SARSCoV-2 due to the expression of the ACE2 in different cellular compartments of the testes [21,33-36]. However, evidence for the presence of the viral particles in the testicular biopsies and semen samples from COVID-19 patients is highly limited $[37,38]$. Despite the unavailability of clear scientific proof for the presence of SARS-CoV-2 in the testes and semen samples, degeneration of seminiferous tubule, reduced number of Leydig cells, and impaired spermatogenesis have been evident in a significant number of COVID-19-positive cases [37-39]. Besides, male subjects with COVID-19 have been reported to exhibit a decreased level of testosterone and altered secretion of the hypothalamus-mediated secretion of gonadotropins such as luteinizing hormone ( $\mathrm{LH})$ and follicle-stimulating hormone(FSH) in the pituitary [37, 40-42]. This article revisits the key reports on testicular abnormalities as well as pathological signatures in the hypothalamus of COVID-19 patients. Further, the article supports a notion that COVID19 patients and survivors might be at risk of infertility due to testicular atrophy, hypothalamic pathology, pituitary abnormalities, and disruption of sex hormone profile. Further investigations are required to monitor the reproductive health parameters and HPG axis abnormalities related to secondary pathological complications in the positive cases during and after the recovery from COVID-19.

\section{Testicular Dysfunction in COVID-19}

The reports on the incidence of testicular pathology in COVID-19 have increasingly been conclusive. It is clear that men are more susceptible to SARS-CoV-2 infection than women $[43,44]$. Abnormal levels of testosterone have been identified as a key determinant for COVID-19-related pathogenesis $[45,46]$. The transcriptome analysis studies of human testicular tissues confirmed the prominent expression of the ACE2 receptor and TMPRSS2 in spermatogonia, spermatids, Leydig cells, and Sertoli cells $[36,47]$. Moreover, the expression of TMPRSS2 has been reported to be upregulated by androgens in men $[48,49]$. Existing reports revealed that the invasion of SARS-CoV-2 also occurs via CD14, a putative marker of spermatogonial stem cells in the testes $[50,51]$. A recent review by Lopez-Romero and colleagues posited that testicular cells could be a possible target for SARS-CoV-2 infection due to the presence of its receptors in the testicular cells [52]. However, the presence of SARS-CoV-2 in the testes and semen samples of COVID-19 patients remains a subject of debate. During the previous outbreak of SARS, Zhao et al. indicated the presence of the virus in the testicular tissue [53]. However, subsequent reports indicated the absence of the viral particles in the testes, though orchitis and testicular atrophy were common [54-56]. Notably, Xu et al. reported a pronounced leukocyte infiltration in the testes in association with atrophy of the seminiferous epithelium in SARS-CoV-1affected patients [56]. Therefore, the possibilities for the breakdown of the blood-testis barrier (BTB) have been speculated in COVID-19 patients [57], which requires experimental validation. Recently, Yang and colleagues have provided reverse transcription-polymerase chain reaction (RT-PCR)based evidence for the presence of SARS-CoV-2 in the testes sample of a COVID-19 patient who was at the active reproductive age [37]. However, a subsequent electron microscopic examination revealed the absence of SARS-CoV-2 in testicular tissues of COVID-19 victims [37]. Further, a study by Pan et al. reported the absence of SARS-CoV-2 in semen samples collected from 34 male patients approximately 31 days after being confirmed positive for COVID-19, while these patients displayed viral orchitis, a clinical state of inflammation of testicles at the time of diagnosis [38]. A similar study by Song et al. further validated the absence of the virus in both acute and recovery phases [58]. However, the aforementioned studies have some limitations including low sample size, mild symptoms in the tested patients, and delayed processing of samples. The examinations were done 31-41 days after the onset of disease, and it is possible that the virus lost its activity 
or was eliminated by an immunological defence mechanism in the testes as the clinical guidelines suggest an incubation period of 14 days for SARS-CoV-2 [59, 60]. Moreover, the electron microscopic finding has been a subject of debate due to possible misinterpretation of the data $[59,60]$. Therefore, it is not clear whether the virus could invade the testicular tissue in the initial stage of SARS-CoV-2 infection since most of the studies were done in the samples at a later stage.

The post-mortem examinations of the human testes suggest that SARS-CoV-2 infections lead to testicular inflammation, edema, and degeneration of spermatogenic cells in association with infiltration of $\mathrm{CD}^{+}$and $\mathrm{CD} 68^{+}$immune cells [56]. Recently, Kim et al. indicated that COVID-19 patients experienced testicular pain regardless of respiratory symptoms [61]. A cohort study conducted by Holtman $\mathrm{N}$ et al. in the semen samples of 18 men recovered from mild to moderate COVID-19 revealed a low sperm count and poor sperm motility, though the viral particles were undetectable in the semen [62]. As the above study was conducted 8-54 days after the disappearance of COVID-19 symptoms, it is unclear whether the viral RNA was present in the semen in the initial stage of the infection. A case study by Özveri et al. indicated that a male asymptomatic patient diagnosed positive for COVID-19 had swelling and severe pain in the left groin and testicle [63]. Another study by La Marca et al. reported that a diabetic patient with severe bilateral testicular pain later developed dyspnea and tested positive for COVID-19 [64]. However, the reports on reduced circulating levels of testosterone in COVID-19 cases clearly suggest the possibility of abnormal spermatogenesis leading to infertility which might be largely due to testicular inflammation [20,65].

Notably, SARS-CoV-2 infection has been reported to induce the circulation of pro-inflammatory cytokines contributing to the pathogenic progression of COVID-19 [66, 67]. In general, pro-inflammatory cytokines and oxidative stressmediated free radicals cause degeneration in cellular components of the testes $[68,69]$. The reduced levels of testosterone and impaired spermatogenesis observed in COVID-19 have also been related to persistent fever, elevated levels of proinflammatory molecules and secondary autoimmune response in the testes [69-71]. Moreover, the treatment regime for COVID-19 patients involves the use of anti-viral drugs like Ribavirin which is known to induce oxidative stress, decrease the levels of testosterone, and cause sperm abnormalities [72, 73]. Taken together, the occurrence of testicular abnormalities, possibly at the level of reduced steroidogenesis and impaired spermatogenesis, can be considered as an important pathogenic event in COVID-19 [74] (Fig. 1). In addition, reduced level of sex steroid hormones resulting from testicular defects might be associated with abnormal regulation of the HPG axis, while the SARS-CoV-2 infection appears to affect the hypothalamus of the brain responsible for the sensing of testes-derived sex steroid hormones. Therefore, understanding the pathological impact of SARS-CoV-2 infection in the brain affecting the hypothalamus might also be highly relevant with reference to abnormal gonadotropin hormone levels.

\section{Altered Levels of Gonadotropins in COVID-19}

The hypothalamus is a crucial region of the brain that generates, integrates, and regulates various physiological processes including the hormonal balance, blood pressure, basal homeostasis, body temperature, circadian rhythm, sexual behavior, and emotion [75-78]. The hypothalamus is functionally linked to the pituitary gland, adrenal gland, and gonads through the circulating levels of stress hormones and gonadal sex steroids [30, 76, 79-81]. In general, the HPG axis is regulated by the release of gonadotropin-releasing hormone $(\mathrm{GnRH})$ from the hypothalamus in response to a decrease in the circulating level of sex steroid hormones especially testosterone in the case of males. FSH and LH are produced in the anterior pituitary by stimulation of the hypothalamus-derived GnRH $[30,31]$. While FSH acts on the Sertoli cells, LH targets Leydig cells in the testes leading to the synthesis of testosterone responsible for spermatogenesis $[82,83]$. As a feedback loop, the circulating concentration of testosterone acts at the hypothalamus to decrease the release of GnRH in order to control the synthesis of FSH and LH in the pituitary $[65,84$, 85]. Local testosterone concentration in the testes is nearly 100 times greater than in the peripheral circulation, and it acts on the Sertoli cells to promote spermatogenesis. In the physiological state, the proper regulation of HPG axis is important for reproductive function, whereas dysfunction of the HPG axis has been reported to disrupt steroidogenesis and spermatogenesis in the testes, thereby leading to infertility and psychological issues [81, 86, 87].

In theory, the neuropathogenic signals observed in the hypothalamus could result in a decreased level of GnRH leading to the suppression of the LH and FSH syntheses in the pituitary. While the evidence for the altered levels of GnRH remains to be established, a recent hormonal assessment-based study by Ma et al. reported an increase in circulating levels of LH in male subjects with COVID-19 contributing to abnormal $\mathrm{FSH} / \mathrm{LH}$ ratios [41]. Çayan $\mathrm{S}$ et al. indicated that the mean values of LH and FSH concentrations rise in the circulation along with the increase in the severity of COVID-19 [42]. During the previous epidemic outbreak of SARS-CoV in 2004, a transmission electron microscopy-based study by Ding et al. revealed that the genome of SARS-CoV integrates into the brain and pituitary gland [54]. A recent neuroimaging finding by Pascual-Goñi et al. revealed a clear hyperintensity signal indicating neurological lesion in the hypothalamus and enlarged pituitary gland in a COVID-19-positive female patient [25]. The hypertrophy noticed in the pituitary gland of 


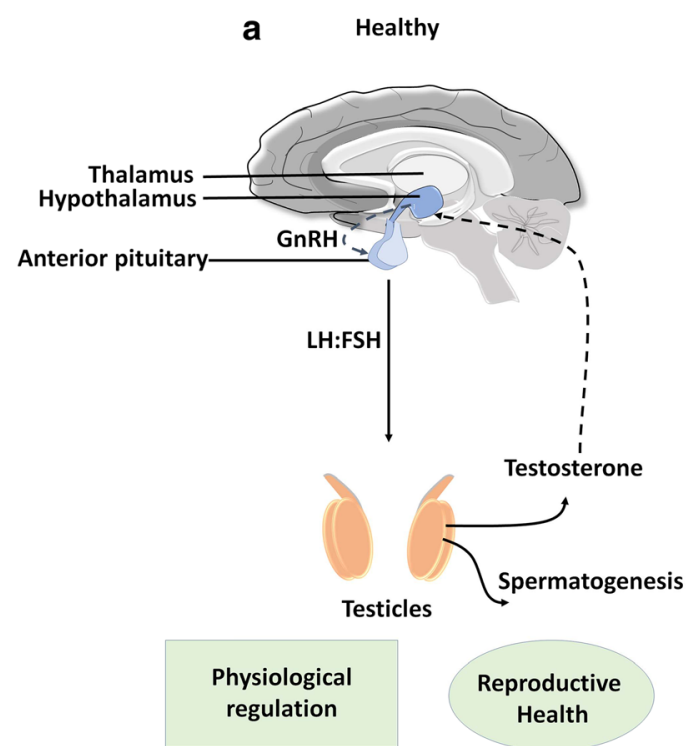

Fig. 1 Schematic representation of the regulation of HPG axis in healthy and COVID-19 conditions. a Represents the healthy human brain and testes in association with the HPG axis. b Represents a SARS-CoV-2

COVID-19 could be a possible reason for the transient surge of the gonadotropins [25]. Hence, it is too early to characterize the basis for the circulating levels of gonadotropins in COVID-19 cases with highly limited availability of scientific data. While a growing body of evidence clearly indicates that testicular pathology occurs due to COVID-19, it could lead to disruption in the regulation of gonadotropins. The regulation of the release of gonadotropins from the pituitary involves the input from the hypothalamus. Therefore, hypothalamic pathology seen in COVID-19 might also be linked with infertility in association with reduced testosterone resulting from testicular atrophy.

\section{Testicular Pathology: a Key Determinant of Infertility and Dysfunction of HPG Axis in COVID-19}

In general, viral infections have been associated with fever due to inflammatory responses and immunogenic reactions [88]. Abnormal activation of immune cells upon viral infection can result in high levels of pro-inflammatory factors including interferon-gamma (INF- $\gamma$ ), tumor necrosis factor (TNF)- $\alpha$, transforming growth factor (TGF)- $\beta$, and different types of interleukins (ILs) [89-91]. In addition, elevated levels of C-reactive proteins (CRP) have been one of the clinical hallmarks of viral infections [92]. Chronic activation of immune cell-derived inflammatory cytokines contributes to pathogenicity in different tissues and organs [93, 94]. While COVID-19 has been characterized by lymphopenia, the spleen and lymph nodes of post-mortem tissues have been

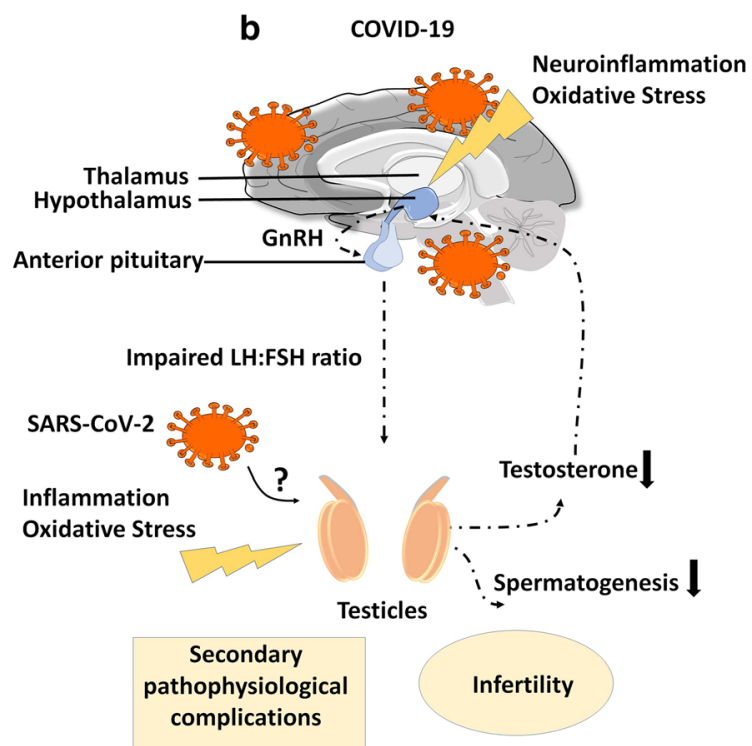

infected human brain and testes with neuroinflammation and dysregulation of the HPG axis in association with reduced steroidogenesis and spermatogenesis due to testicular inflammation and oxidative stress.

characterized by the accumulation of ACE2-positive macrophages [8, 95-98]. In particular, the unregulatable activation of immune cells like lymphocytes and macrophages that are responsible for the surplus levels of inflammatory cytokines could lead to oxidative stress and cell death in different organs including the brain and testes $[68,70,99]$. Among the various organs, the testes have been known to be highly vulnerable to the enhanced inflammatory molecules and free radicalmediated oxidative stress $[68,70]$. Notably, the proinflammatory cytokines and oxidative stress are highly detrimental to the steroidogenesis and spermatogenesis in the testes $[68,70]$. In numerous pathogenic conditions, elevated CRP and aberrant cytokine release such as INF- $\gamma$ have been known to induce defects in steroidogenesis and spermatogenesis in the testes. Taken together, given the massive cytokine storm reported, the testes are at risk of structural and functional dysfunctions in subjects with COVID-19 regardless of the direct infection of SARS-CoV-2 in the testes [74, 100, 101].

In healthy individuals, the hypothalamus of the brain senses the circulating levels of testosterone and stimulates the pituitary gland to secrete $\mathrm{LH}$ and FSH through GnRH as a feedback mechanism, whereas in testicular pathogenesis, reduction in the testosterone level might lead to the dysregulation of the production of $\mathrm{GnRH}$ in the hypothalamus followed by the abnormal secretion of LH and FSH from the pituitary $[30,32,81,87,102]$. The increased circulating levels of LH and FSH reported in COVID-19 cases [41, 42] could indicate the transient activation of the gonadotropinproducing cells due to early inflammatory responses (Fig. 1). While testosterone, FSH, and LH are collectively involved in the physiological regulation of the reproductive system, the 
onset and progression of sexual disorders and infertility have been attributed to testicular pathology and dysregulation of the HPG axis [103, 104]. Thus, it can be expected that COVID-19 survivors might be at a greater risk of developing sexual disorders and infertility-related issues (Fig. 1).

\section{Conclusion}

Although the presence of SARS-CoV-2 in the testes remains controversial, hypogonadism resulting from the inflammation in the testes is increasingly evident $[105,106]$. Thus, a defect in the steroidogenesis in the testes reflected by the reduced level of testosterone may be the underlying basis for the abnormal levels of FSH and LH in patients with COVID-19. In turn, low testosterone levels could lead to defects in spermatogenesis, erectile dysfunction, and infertility in COVID-19 [30, 107]. Therefore, understanding the impact of COVID-19 on testicular pathology has become an important clinical responsibility. FSH and LH have also been known to play roles in non-reproductive functions, while increased levels of FSH and LH have been reported to be the biomarkers for testicular damage and some secondary pathological consequences $[108$, 109]. The dysregulation of the HPG axis has been associated with diseases like chronic kidney disease and liver cirrhosis [110-113]. Also, the incidence of disorders of HPG axis ranging from hypothyroidism to neurodegenerative senescence could be a likely consequence $[102,114,115]$. Therefore, a detailed study of the endocrinological and reproductive parameters of COVID-19 patients has become inevitable.

\begin{abstract}
Acknowledgments The authors acknowledge UGC-SAP and DST-FIST for the infrastructure of the Department of Animal Science, Bharathidasan University. Also, the authors gratefully acknowledge Prof. Erma Z. Drobnis, Mrs. Raji Nirmal, and anonymous reviewers for their critical reading and insightful suggestions on the manuscript.
\end{abstract}

Funding M.K. has been supported by the Faculty Recharge Programme, University Grants Commission (UGC-FRP), New Delhi, India. M.K. received a research grant (SERB-EEQ/2016/000639), an Early Career Research Award (SERB-ECR/2016/000741) from the Science and Engineering Research Board (SERB), government of India and financial assistance from RUSA (Rashtriya Uchchatar Shiksha Abhiyan) PHASE II, Biological Sciences. R.K.R. has been supported as JRF from the project grant-ECR/2016/000741, SERB.

\section{Compliance with Ethical Standards}

Conflict of Interest The authors declare that they have no conflict of interest.

\section{References}

1. Chan JF-W, Yuan S, Kok K-H, To KK-W, Chu H, Yang J, et al. A familial cluster of pneumonia associated with the 2019 novel coronavirus indicating person-to-person transmission: a study of a family cluster. Lancet. 2020;395:514-23. https://doi.org/10. 1016/S0140-6736(20)30154-9.

2. Li H, Liu S-M, Yu X-H, Tang S-L, Tang C-K. Coronavirus disease 2019 (COVID-19): current status and future perspectives. Int J Antimicrob Agents. 2020;55:105951. https://doi.org/10.1016/j. ijantimicag.2020.105951.

3. Guo Y-R, Cao Q-D, Hong Z-S, Tan Y-Y, Chen S-D, Jin H-J, et al. The origin, transmission and clinical therapies on coronavirus disease 2019 (COVID-19) outbreak - an update on the status. Mil Med Res. 2020;7:11. https://doi.org/10.1186/s40779-020-002400 .

4. Zhou P, Yang X-L, Wang X-G, Hu B, Zhang L, Zhang W, et al. A pneumonia outbreak associated with a new coronavirus of probable bat origin. Nature. 2020;579:270-3. https://doi.org/10.1038/ s41586-020-2012-7.

5. Zheng J. SARS-CoV-2: an emerging coronavirus that causes a global threat. Int J Biol Sci. 2020;16:1678-85. https://doi.org/10. 7150/ijbs.45053.

6. Lai C-C, Liu YH, Wang C-Y, Wang Y-H, Hsueh S-C, Yen M-Y, et al. Asymptomatic carrier state, acute respiratory disease, and pneumonia due to severe acute respiratory syndrome coronavirus 2 (SARS-CoV-2): facts and myths. J Microbiol Immunol Infect. 2020;53:404-12. https://doi.org/10.1016/j.jmii.2020.02.012.

7. Jordan RE, Adab P, Cheng KK. Covid-19: risk factors for severe disease and death. BMJ. 2020;368:m1198. https://doi.org/10. 1136/bmj.m1198.

8. Kandasamy M. Perspectives for the use of therapeutic Botulinum toxin as a multifaceted candidate drug to attenuate COVID-19. Med Drug Discov. 2020:100042. https://doi.org/10.1016/j. medidd.2020.100042.

9. Gu J, Han B, Wang J. COVID-19: gastrointestinal manifestations and potential fecal-oral transmission. Gastroenterology. 2020;158:1518-9. https://doi.org/10.1053/j.gastro.2020.02.054.

10. Li R, Yin T, Fang F, Li Q, Chen J, Wang Y, et al. Potential risks of SARS-Cov-2 infection on reproductive health. Reprod BioMed Online. 2020;41:89-95. https://doi.org/10.1016/j.rbmo.2020.04. 018.

11. Long B, Brady WJ, Koyfman A, Gottlieb M. Cardiovascular complications in COVID-19. Am J Emerg Med. 2020;38:1504-7. https://doi.org/10.1016/j.ajem.2020.04.048.

12. Wu Y, Xu X, Chen Z, Duan J, Hashimoto K, Yang L, et al. Nervous system involvement after infection with COVID-19 and other coronaviruses. Brain Behav Immun. 2020;87:18-22. https:// doi.org/10.1016/j.bbi.2020.03.031.

13. Xu Z, Shi L, Wang Y, Zhang J, Huang L, Zhang C, et al. Pathological findings of COVID-19 associated with acute respiratory distress syndrome. Lancet Respir Med. 2020;8:420-2. https://doi.org/10.1016/S2213-2600(20)30076-X.

14. Belouzard S, Millet JK, Licitra BN, Whittaker GR. Mechanisms of coronavirus cell entry mediated by the viral spike protein. Viruses. 2012;4:1011-33. https://doi.org/10.3390/v4061011.

15. Hoffmann M, Kleine-Weber H, Schroeder S, Krüger N, Herrler T, Erichsen S, et al. SARS-CoV-2 cell entry depends on ACE2 and TMPRSS 2 and is blocked by a clinically proven protease inhibitor. Cell. 2020;181:271-280.e8. https://doi.org/10.1016/j.cell. 2020.02.052.

16. Vaarala MH, Porvari KS, Kellokumpu S, Kyllönen AP, Vihko PT. Expression of transmembrane serine protease TMPRSS2 in mouse and human tissues. J Pathol. 2001;193:134-40. https://doi.org/10. 1002/1096-9896(2000)9999:9999<::AID-PATH743>3.0.CO;2$\mathrm{T}$.

17. Hamming I, Timens W, Bulthuis MLC, Lely AT, Navis GJ, van Goor H. Tissue distribution of ACE2 protein, the functional receptor for SARS coronavirus. A first step in understanding SARS 
pathogenesis. J Pathol. 2004;203:631-7. https://doi.org/10.1002/ path.1570.

18. Cao X. COVID-19: immunopathology and its implications for therapy. Nat Rev Immunol. 2020;20:1-2. https://doi.org/10. 1038/s41577-020-0308-3.

19. Arbour N, Day R, Newcombe J, Talbot PJ. Neuroinvasion by human respiratory coronaviruses. J Virol. 2000;74:8913-21. https://doi.org/10.1128/JVI.74.19.8913-8921.2000.

20. Abobaker A, Raba AA. Does COVID-19 affect male fertility? World J Urol. 2020:1-2. https://doi.org/10.1007/s00345-02003208-w.

21. Chen F, Lou D. Rising concern on damaged testis of COVID-19 patients. Urology. 2020;142:42. https://doi.org/10.1016/j.urology. 2020.04.069.

22. Sepehrinezhad A, Shahbazi A, Negah SS. COVID-19 virus may have neuroinvasive potential and cause neurological complications: a perspective review. J Neuro-Oncol. 2020;26:1-6. https:// doi.org/10.1007/s13365-020-00851-2.

23. Das G, Mukherjee N, Ghosh S. Neurological insights of COVID19 pandemic. ACS Chem Neurosci. 2020;11:1206-9. https://doi. org/10.1021/acschemneuro.0c00201.

24. Li Y-C, Bai W-Z, Hashikawa T. The neuroinvasive potential of SARS-CoV2 may play a role in the respiratory failure of COVID19 patients. J Med Virol. 2020;92:552-5. https://doi.org/10.1002/ jmv.25728.

25. Pascual-Goñi E, Fortea J, Martínez-Domeño A, Rabella N, Tecame M, Gómez-Oliva C, et al. COVID-19-associated ophthalmoparesis and hypothalamic involvement. Neurol Neuroimmunol Neuroinflamm. 2020;7:e823. https://doi.org/10. 1212/NXI.0000000000000823.

26. Baig AM, Khaleeq A, Ali U, Syeda H. Evidence of the COVID-19 virus targeting the CNS: tissue distribution, host-virus interaction, and proposed neurotropic mechanisms. ACS Chem Neurosci. 2020;11:995-8. https://doi.org/10.1021/acschemneuro.0c00122.

27. $\mathrm{Yu}$ J. Endocrine disorders and the neurologic manifestations. Ann Pediatr Endocrinol Metab. 2014;19:184-90. https://doi.org/10. 6065/apem.2014.19.4.184.

28. Ranabir S, Reetu K. Stress and hormones. Indian J Endocrinol Metab. 2011;15:18-22. https://doi.org/10.4103/2230-8210. 77573.

29. Tsigos C, Kyrou I, Kassi E, Chrousos GP. Stress, endocrine physiology and pathophysiology. In: Feingold KR, Anawalt B, Boyce A, Chrousos G, de Herder WW, Dungan K, et al., editors. Endotext. South Dartmouth: MDText.com, Inc.; 2000.

30. Kandasamy M, Radhakrishnan RK, Poornimai Abirami GP, Roshan SA, Yesudhas A, Balamuthu K, et al. Possible existence of the hypothalamic-pituitary-hippocampal ( $\mathrm{HPH})$ axis: a reciprocal relationship between hippocampal specific neuroestradiol synthesis and neuroblastosis in ageing brains with special reference to menopause and neurocognitive disorders. Neurochem Res. 2019;44:1781-95. https://doi.org/10.1007/s11064-019-02833-1.

31. Pal R. COVID-19, hypothalamo-pituitary-adrenal axis and clinical implications. Endocrine. 2020;68:1-2. https://doi.org/10.1007/ s12020-020-02325-1.

32. Oyola MG, Handa RJ. Hypothalamic-pituitary-adrenal and hypothalamic-pituitary-gonadal axes: sex differences in regulation of stress responsivity. Stress. 2017;20:476-94. https://doi.org/10. 1080/10253890.2017.1369523.

33. Verma S, Saksena S, Sadri-Ardekani H. ACE2 receptor expression in testes: implications in coronavirus disease 2019 pathogenesis†. Biol Reprod. 2020;103:449-51. https://doi.org/10.1093/ biolre/ioaa080.

34. Cardona Maya WD, Du Plessis SS, Velilla PA. SARS-CoV-2 and the testis: similarity with other viruses and routes of infection. Reprod BioMed Online. 2020;40:763-4. https://doi.org/10.1016/ j.rbmo.2020.04.009.
35. Shen Q, Xiao X, Aierken A, Yue W, Wu X, Liao M, et al. The ACE2 expression in Sertoli cells and germ cells may cause male reproductive disorder after SARS-CoV-2 infection. J Cell Mol Med. 2020;24:9472-7. https://doi.org/10.1111/jcmm.15541.

36. Stanley KE, Thomas E, Leaver M, Wells D. Coronavirus disease19 and fertility: viral host entry protein expression in male and female reproductive tissues. Fertil Steril. 2020;114:33-43. https:// doi.org/10.1016/j.fertnstert.2020.05.001.

37. Yang M, Chen S, Huang B, Zhong J-M, Su H, Chen Y-J, et al. Pathological findings in the testes of COVID-19 patients: clinical implications. Eur Urol Focus. 2020;6:1124-9. https://doi.org/10. 1016/j.euf.2020.05.009.

38. Pan F, Xiao X, Guo J, Song Y, Li H, Patel DP, et al. No evidence of severe acute respiratory syndrome-coronavirus 2 in semen of males recovering from coronavirus disease 2019. Fertil Steril. 2020;113:1135-9. https://doi.org/10.1016/j.fertnstert.2020.04. 024.

39. Wang S, Zhou X, Zhang T, Wang Z. The need for urogenital tract monitoring in COVID-19. Nat Rev Urol. 2020;17:1-2. https://doi. org/10.1038/s41585-020-0319-7.

40. Vishvkarma R, Rajender S. Could SARS-CoV-2 affect male fertility? Andrologia. 2020;52:e13712. https://doi.org/10.1111/and. 13712.

41. Ma L, Xie W, Li D, Shi L, Ye G, Mao Y, et al. Evaluation of sexrelated hormones and semen characteristics in reproductive-aged male COVID-19 patients. J Med Virol. 2020. https://doi.org/10. $1002 /$ jmv.26259.

42. Çayan S, Uğuz M, Saylam B, Akbay E. Effect of serum total testosterone and its relationship with other laboratory parameters on the prognosis of coronavirus disease 2019 (COVID-19) in SARS-CoV-2 infected male patients: a cohort study. Aging Male. 2020:1-11. https://doi.org/10.1080/13685538.2020. 1807930.

43. Karlberg J, Chong DSY, Lai WYY. Do men have a higher case fatality rate of severe acute respiratory syndrome than women do? Am J Epidemiol. 2004;159:229-31. https://doi.org/10.1093/aje/ kwh056.

44. Jin J-M, Bai P, He W, Wu F, Liu X-F, Han D-M, et al. Gender differences in patients with COVID-19: focus on severity and mortality. Front Public Health. 2020;8. https://doi.org/10.3389/ fpubh.2020.00152.

45. Channappanavar R, Fett C, Mack M, Ten Eyck PP, Meyerholz DK, Perlman S. Sex-based differences in susceptibility to SARSCoV infection. J Immunol. 2017;198:4046-53. https://doi.org/10. 4049/jimmunol.1601896.

46. Salonia A, Corona G, Giwercman A, Maggi M, Minhas S, Nappi $\mathrm{RE}$, et al. SARS-CoV-2, testosterone and frailty in males (PROTEGGIMI): a multidimensional research project. Andrology. 2020. https://doi.org/10.1111/andr.12811.

47. Wang $\mathrm{Z}, \mathrm{Xu} \mathrm{X}$. scRNA-seq profiling of human testes reveals the presence of the ACE2 receptor, a target for SARS-CoV-2 infection in spermatogonia, Leydig and Sertoli cells. Cells. 2020:9. https://doi.org/10.3390/cells9040920.

48. Clinckemalie L, Spans L, Dubois V, Laurent M, Helsen C, Joniau $\mathrm{S}$, et al. Androgen regulation of the TMPRSS2 gene and the effect of a SNP in an androgen response element. Mol Endocrinol. 2013;27:2028-40. https://doi.org/10.1210/me.2013-1098.

49. Lucas JM, Heinlein C, Kim T, Hernandez SA, Malik MS, True $\mathrm{LD}$, et al. The androgen-regulated protease TMPRSS2 activates a proteolytic cascade involving components of the tumor microenvironment and promotes prostate cancer metastasis. Cancer Discov. 2014;4:1310-25. https://doi.org/10.1158/2159-8290. CD-13-1010.

50. Chen Z, Mi L, Xu J, Yu J, Wang X, Jiang J, et al. Function of HAb18G/CD147 in invasion of host cells by severe acute 
respiratory syndrome coronavirus. J Infect Dis. 2005;191:755-60. https://doi.org/10.1086/427811.

51. Ulrich H, Pillat MM. CD147 as a target for COVID-19 treatment: suggested effects of azithromycin and stem cell engagement. Stem Cell Rev Rep. 2020;16:1-7. https://doi.org/10.1007/s12015-02009976-7.

52. López-Romero R, Nambo-Lucio M d J, Salcedo-Carrillo E, Hernández-Cueto M d LÁ, Salcedo-Vargas M. The big challenge of SARS-CoV-2 latency: testes as reservoir. Gac Med Mex. 2020;156:328-33. https://doi.org/10.24875/GMM.20000295.

53. Zhao J, Zhou G, Sun Y, Wang S, Yang J, Meng E, et al. Clinical pathology and pathogenesis of severe acute respiratory syndrome. Zhonghua Shi Yan He Lin Chuang Bing Du Xue Za Zhi. 2003;17: 217-21.

54. Ding Y, He L, Zhang Q, Huang Z, Che X, Hou J, et al. Organ distribution of severe acute respiratory syndrome (SARS) associated coronavirus (SARS-CoV) in SARS patients: implications for pathogenesis and virus transmission pathways. J Pathol. 2004;203:622-30. https://doi.org/10.1002/path.1560.

55. Gu J, Gong E, Zhang B, Zheng J, Gao Z, Zhong Y, et al. Multiple organ infection and the pathogenesis of SARS. J Exp Med. 2005;202:415-24. https://doi.org/10.1084/jem.20050828.

56. Xu J, Qi L, Chi X, Yang J, Wei X, Gong E, et al. Orchitis: a complication of severe acute respiratory syndrome (SARS)1. Biol Reprod. 2006;74:410-6. https://doi.org/10.1095/biolreprod. 105.044776.

57. Olaniyan OT, Dare A, Okotie GE, Adetunji CO, Ibitoye BO, Bamidele OJ, et al. Testis and blood-testis barrier in Covid-19 infestation: role of angiotensin-converting enzyme 2 in male infertility. J Basic Clin Physiol Pharmacol. 2020;0. https://doi.org/ 10.1515/jbcpp-2020-0156.

58. Song C, Wang Y, Li W, Hu B, Chen G, Xia P, et al. Absence of 2019 novel coronavirus in semen and testes of COVID-19 patients. Biol Reprod. 2020;103:4-6. https://doi.org/10.1093/ biolre/ioaa050.

59. Dittmayer C, Meinhardt J, Radbruch H, Radke J, Heppner BI, Heppner FL, et al. Why misinterpretation of electron micrographs in SARS-CoV-2-infected tissue goes viral. Lancet. 2020;396:e64 5. https://doi.org/10.1016/S0140-6736(20)32079-1.

60. Goldsmith CS, Miller SE, Martines RB, Bullock HA, Zaki SR. Electron microscopy of SARS-CoV-2: a challenging task. Lancet. 2020;395:e99. https://doi.org/10.1016/S0140-6736(20)31188-0.

61. Kim J, Thomsen T, Sell N, Goldsmith AJ. Abdominal and testicular pain: an atypical presentation of COVID-19. Am J Emerg Med. 2020;38:1542.e1-3. https://doi.org/10.1016/j.ajem.2020. 03.052

62. Holtmann N, Edimiris P, Andree M, Doehmen C, Baston-Buest $\mathrm{D}$, Adams $\mathrm{O}$, et al. Assessment of SARS-CoV-2 in human semena cohort study. Fertil Steril. 2020;114:233-8. https://doi.org/10. 1016/j.fertnstert.2020.05.028.

63. Özveri H, Eren MT, Kırışoğlu CE, Sarıgüzel N. Atypical presentation of SARS-CoV-2 infection in male genitalia. Urol Case Rep. 2020;33:101349. https://doi.org/10.1016/j.eucr.2020.101349.

64. La Marca A, Busani S, Donno V, Guaraldi G, Ligabue G, Girardis M. Testicular pain as an unusual presentation of COVID-19: a brief review of SARS-CoV-2 and the testis. Reprod BioMed Online. 2020;41:903-6. https://doi.org/10.1016/j.rbmo.2020.07. 017

65. Pozzilli P, Lenzi A. Testosterone, a key hormone in the context of COVID-19 pandemic. Metabolism. 2020;108:154252. https://doi. org/10.1016/j.metabol.2020.154252.

66. Shi Y, Wang Y, Shao C, Huang J, Gan J, Huang X, et al. COVID19 infection: the perspectives on immune responses. Cell Death Differ. 2020;27:1-4. https://doi.org/10.1038/s41418-020-0530-3.

67. Tay MZ, Poh CM, Rénia L, MacAry PA, Ng LFP. The trinity of COVID-19: immunity, inflammation and intervention. Nat Rev
Immunol. 2020;20:363-74. https://doi.org/10.1038/s41577-0200311-8.

68. Aitken RJ, Roman SD. Antioxidant systems and oxidative stress in the testes. Oxidative Med Cell Longev. 2008;1:15-24.

69. Asadi N, Bahmani M, Kheradmand A, Rafieian-Kopaei M. The impact of oxidative stress on testicular function and the role of antioxidants in improving it: a review. J Clin Diagn Res. 2017;11:IE01-5. https://doi.org/10.7860/JCDR/2017/23927. 9886

70. Abd-Allah AR, Helal GK, Al-Yahya AA, Aleisa AM, Al-Rejaie SS, Al-Bakheet SA. Pro-inflammatory and oxidative stress pathways which compromise sperm motility and survival may be altered by L-carnitine. Oxidative Med Cell Longev. 2009;2:73-81.

71. Youssef K, Abdelhak K. Male genital damage in COVID-19 patients: are available data relevant? Asian J Urol. 2020. https://doi. org/10.1016/j.ajur.2020.06.005.

72. Almasry SM, Hassan ZA, Elsaed WM, Elbastawisy YM. Structural evaluation of the peritubular sheath of rat's testes after administration of ribavirin: a possible impact on the testicular function. Int J Immunopathol Pharmacol. 2017;30:282-96. https://doi.org/10.1177/0394632017726261.

73. Narayana K, D'Souza UJA, Narayan P, Kumar G. The antiviral drug ribavirin reversibly affects the reproductive parameters in the male Wistar rat. Folia Morphol (Warsz). 2005;64:65-71.

74. Ma L, Xie W, Li D, Shi L, Mao Y, Xiong Y, et al. Effect of SARSCoV-2 infection upon male gonadal function: a single centerbased study. MedRxiv 2020:2020.03.21.20037267. https://doi. org/10.1101/2020.03.21.20037267.

75. Fassbender K, Schmidt R, Mössner R, Kischka U, Kühnen J, Schwartz A, et al. Mood disorders and dysfunction of the hypothalamic-pituitary-adrenal axis in multiple sclerosis: association with cerebral inflammation. Arch Neurol. 1998;55:66-72. https://doi.org/10.1001/archneur.55.1.66.

76. Lechan RM, Toni R. Functional anatomy of the hypothalamus and pituitary. In: Feingold KR, Anawalt B, Boyce A, Chrousos G, Dungan K, Grossman A, et al., editors. Endotext. South Dartmouth: MDText.com, Inc.; 2000.

77. Saper CB, Scammell TE, Lu J. Hypothalamic regulation of sleep and circadian rhythms. Nature. 2005;437:1257-63. https://doi. org/10.1038/nature04284.

78. Guijarro A, Laviano A, Meguid MM. Hypothalamic integration of immune function and metabolism. Prog Brain Res. 2006;153: 367-405. https://doi.org/10.1016/S0079-6123(06)53022-5.

79. Daniel PM. Anatomy of the hypothalamus and pituitary gland. J Clin Pathol Suppl (Assoc Clin Pathol). 1976;7:1-7.

80. Smith SM, Vale WW. The role of the hypothalamic-pituitaryadrenal axis in neuroendocrine responses to stress. Dialogues Clin Neurosci. 2006;8:383-95.

81. Selvaraj K, Manickam N, Kumaran E, Thangadurai K, Elumalai G, Sekar A, et al. Deterioration of neuroregenerative plasticity in association with testicular atrophy and dysregulation of the hypothalamic-pituitary-gonadal (HPG) axis in Huntington's disease: a putative role of the huntingtin gene in steroidogenesis. J Steroid Biochem Mol Biol. 2020;197:105526. https://doi.org/10. 1016/j.jsbmb.2019.105526.

82. Kliesch S, Schweifer B, Niklowitz P, Nieschlag E, Bergmann M. The influence of LH and/or FSH on Leydig and Sertoli cell morphology after testicular involution in the Djungarian hamster, Phodopus sungorus, induced by hypophysectomy or short photoperiods. Andrologia. 1991;23:99-107. https://doi.org/10.1111/j. 1439-0272.1991.tb02511.x.

83. Ramaswamy S, Weinbauer GF. Endocrine control of spermatogenesis: role of FSH and LH/ testosterone. Spermatogenesis. 2015;4:e996025. https://doi.org/10.1080/21565562.2014.996025.

84. Plant TM. The hypothalamo-pituitary-gonadal axis. J Endocrinol. 2015;226:T41-54. https://doi.org/10.1530/JOE-15-0113. 
85. Clavijo RI, Hsiao W. Update on male reproductive endocrinology. Transl Androl Urol. 2018;7:S367-72. https://doi.org/10.21037/ tau.2018.03.25

86. Viau V. Functional cross-talk between the hypothalamic-pituitarygonadal and -adrenal axes. J Neuroendocrinol. 2002;14:506-13. https://doi.org/10.1046/j.1365-2826.2002.00798.x.

87. Acevedo-Rodriguez A, Kauffman AS, Cherrington BD, Borges CS, Roepke TA, Laconi M. Emerging insights into hypothalamicpituitary-gonadal axis regulation and interaction with stress signalling. J Neuroendocrinol. 2018;30:e12590. https://doi.org/10. 1111/jne. 12590 .

88. Julkunen I, Melén K, Nyqvist M, Pirhonen J, Sareneva T, Matikainen S. Inflammatory responses in influenza A virus infection. Vaccine. 2000;19(Suppl 1):S32-7. https://doi.org/10.1016/ s0264-410x(00)00275-9.

89. Mogensen TH, Paludan SR. Molecular pathways in virus-induced cytokine production. Microbiol Mol Biol Rev. 2001;65:131-50. https://doi.org/10.1128/MMBR.65.1.131-150.2001.

90. Malmgaard L. Induction and regulation of IFNs during viral infections. J Interf Cytokine Res. 2004;24:439-54. https://doi.org/ $10.1089 / 1079990041689665$.

91. Osuji FN, Onyenekwe CC, Ahaneku JE, Ukibe NR. The effects of highly active antiretroviral therapy on the serum levels of proinflammatory and anti-inflammatory cytokines in HIV infected subjects. J Biomed Sci. 2018;25:88. https://doi.org/10.1186/ s12929-018-0490-9.

92. Sproston NR, Ashworth JJ. Role of C-reactive protein at sites of inflammation and infection. Front Immunol. 2018;9. https://doi. org/10.3389/fimmu.2018.00754.

93. Jaffer U, Wade RG, Gourlay T. Cytokines in the systemic inflammatory response syndrome: a review. HSR Proc Intensive Care Cardiovasc Anesth. 2010;2:161-75.

94. Kany S, Vollrath JT, Relja B. Cytokines in inflammatory disease. Int J Mol Sci. 2019;20. https://doi.org/10.3390/ijms20236008.

95. Aziz M, Fatima R, Assaly R. Elevated interleukin-6 and severe COVID-19: a meta-analysis. J Med Virol. 2020;92:2283-5. https://doi.org/10.1002/jmv.25948.

96. Giamarellos-Bourboulis EJ, Netea MG, Rovina N, Akinosoglou $\mathrm{K}$, Antoniadou A, Antonakos N, et al. Complex immune dysregulation in COVID-19 patients with severe respiratory failure. Cell Host Microbe. 2020;27:992-1000.e3. https://doi.org/10.1016/j. chom.2020.04.009.

97. Yuki K, Fujiogi M, Koutsogiannaki S. COVID-19 pathophysiology: a review. Clin Immunol. 2020;215:108427. https://doi.org/ 10.1016/j.clim.2020.108427.

98. Zhang W, Zhao Y, Zhang F, Wang Q, Li T, Liu Z, et al. The use of anti-inflammatory drugs in the treatment of people with severe coronavirus disease 2019 (COVID-19): the perspectives of clinical immunologists from China. Clin Immunol. 2020;214:108393. https://doi.org/10.1016/j.clim.2020.108393.

99. Leszek J, Barreto GE, Gąsiorowski K, Koutsouraki E, ÁvilaRodrigues M, Aliev G. Inflammatory mechanisms and oxidative stress as key factors responsible for progression of neurodegeneration: role of brain innate immune system. CNS Neurol Disord Drug Targets. 2016;15:329-36. https://doi.org/10.2174/ 1871527315666160202125914.

100. Dandona P, Rosenberg MT. A practical guide to male hypogonadism in the primary care setting. Int J Clin Pract. 2010;64:682-96. https://doi.org/10.1111/j.1742-1241.2010. 02355.x.
101. Tremellen K, McPhee N, Pearce K, Benson S, Schedlowski M, Engler H. Endotoxin-initiated inflammation reduces testosterone production in men of reproductive age. Am J Physiol Endocrinol Metab. 2018;314:E206-13. https://doi.org/10.1152/ajpendo. 00279.2017.

102. Fischer S, Ehlert U, Amiel CR. Hormones of the hypothalamicpituitary-gonadal (HPG) axis in male depressive disorders - a systematic review and meta-analysis. Front Neuroendocrinol. 2019;55:100792. https://doi.org/10.1016/j.yfrne.2019.100792.

103. Mastorakos G, Pavlatou MG, Mizamtsidi M. The hypothalamicpituitary-adrenal and the hypothalamic-pituitary-gonadal axes interplay. Pediatr Endocrinol Rev. 2006;3(Suppl 1):172-81.

104. Whirledge S, Cidlowski JA. Glucocorticoids, stress, and fertility. Minerva Endocrinol. 2010;35:109-25.

105. Sansone A, Mollaioli D, Ciocca G, Limoncin E, Colonnello E, Vena W, et al. Addressing male sexual and reproductive health in the wake of COVID-19 outbreak. J Endocrinol Investig. 2020. https://doi.org/10.1007/s40618-020-01350-1.

106. Dutta S, Sengupta P. SARS-CoV-2 and male infertility: possible multifaceted pathology. Reprod Sci. 2020:1-4. https://doi.org/10. 1007/s43032-020-00261-z.

107. Mieusset R, Bujan L, Plantavid M, Grandjean H. Increased levels of serum follicle-stimulating hormone and luteinizing hormone associated with intrinsic testicular hyperthermia in oligospermic infertile men. J Clin Endocrinol Metab. 1989;68:419-25. https:// doi.org/10.1210/jcem-68-2-419.

108. Lizneva D, Rahimova A, Kim S-M, Atabiekov I, Javaid S, Alamoush B, et al. FSH beyond fertility. Front Endocrinol (Lausanne). 2019;10:136. https://doi.org/10.3389/fendo.2019. 00136 .

109. Nedresky D, Singh G. Physiology, luteinizing hormone. StatPearls, Treasure Island: StatPearls Publishing; 2020.

110. Levitan D, Moser SA, Goldstein DA, Kletzky OA, Lobo RA, Massry SG. Disturbances in the hypothalamic-pituitary-gonadal axis in male patients with acute renal failure. Am J Nephrol. 1984;4:99-106. https://doi.org/10.1159/000166785.

111. Holley JL. The hypothalamic-pituitary axis in men and women with chronic kidney disease. Adv Chronic Kidney Dis. 2004;11: 337-41.

112. Zacharias BT, Coelho JCU, Parolin MB, Matias JEF, de Freitas ACT, de Godoy JL. Hypothalamic-pituitary-gonadal function in men with liver cirrhosis before and after liver transplantation. Rev Col Bras Cir. 2014;41:421-5. https://doi.org/10.1590/010069912014006007.

113. Neong SF, Billington EO, Congly SE. Sexual dysfunction and sex hormone abnormalities in patients with cirrhosis: review of pathogenesis and management. Hepatology. 2019;69:2683-95. https://doi.org/10.1002/hep.30359.

114. Atwood CS, Meethal SV, Liu T, Wilson AC, Gallego M, Smith MA, et al. Dysregulation of the hypothalamic-pituitary-gonadal axis with menopause and andropause promotes neurodegenerative senescence. J Neuropathol Exp Neurol. 2005;64:93-103. https:// doi.org/10.1093/jnen/64.2.93.

115. Meikle AW. The interrelationships between thyroid dysfunction and hypogonadism in men and boys. Thyroid. 2004;14(Suppl 1): S17-25. https://doi.org/10.1089/105072504323024552.

Publisher's Note Springer Nature remains neutral with regard to jurisdictional claims in published maps and institutional affiliations. 